\title{
ДИЗАЙН ЕКСПЕРИМЕНТУ ПРИ ПРОВЕДЕННІ ДОСЛІДЖЕНЬ ЗІ СТВОРЕННЯ ТАБЛЕТОВАНИХ ЛІКАРСЬКИХ ЗАСОБІВ ПОВІДОМЛЕННЯ 4. ВИКОРИСТАННЯ МЕТОДУ «ЯКІСТЬ ШЛЯХОМ РОЗРОБКИ» (QbD) ПРИ ОПТИМІЗАЦІї СКЛАДУ ТА ТЕХНОЛОГІЇ ТАБЛЕТОВАНИХ ЛІКАРСЬКИХ ЗАСОБIB
}

\author{
Т. А. Грошовий ${ }^{1}$ Б. В. Павлюк ${ }^{1}$ М. Б. Чубка ${ }^{1}$, М. Б. Демчук ${ }^{1}$, Ю. В. Найда ${ }^{2}$ \\ Тернопільський національний медичний університет імені І. Я. Горбачевського МОЗ \\ України ${ }^{1}$ \\ ПАТ «Фармак»² \\ hrochovuy@tdmu.edu.ua
}

ІНФОРМАЦІЯ

Надійшла до редакції / Received: 25.05.2021

Після доопрацювання / Revised: 02.06.2021

Прийнято до друку / Accepted: 04.06.2021

\section{Ключові слова:}

дизайн експерименту; якість шляхом розробки; математичне планування експерименту;

таблетовані лікарські засоби.

\begin{abstract}
АНОТАЦІЯ
Мета роботи. Аналіз і систематизація даних літератури щодо використання підходу «Якість шляхом розробки» (Quality by Design) 3 метою розробки оптимального складу та технології таблетованих лікарських засобів.

Матеріали і методи. У роботі використано методи інорормаційного пошуку, аналізу даних наукової літератури щодо можливого застосування підходу «Якість шляхом розробки» та практичного його використання при розробці складу та технології таблетованих лікарських засобів.

Результати й обговорення. У роботі охарактеризована загальна концепція підходу «Якість шляхом розробки» у фармацевтичній технології лікарських засобів. Наведено дані щодо практичного застосування даного підходу при розробці складу та технології таблетованих лікарських засобів та їхньої оптимізації.

Висновки. «Якість шляхом розробки» $\epsilon$ важливою та широко використовуваною стратегією розробки лікарських засобів. При використанні даного підходу основну увагу приділяють безпеці та ефективності лікарського засобу, узагальнюють технологічне розуміння фрармацевтичного процесу та застосовуваних методів, здійснюють наукове обґрунтування оцінки ризиків, визначення критичних показників якості та аналіз їхнього впливу на кінцеву якість розробленого засобу.
\end{abstract}

Вступ. У фрармацевтичній технології, яка намагається адаптуватися до швидко мінливих інновацій, за останні роки відбулися важливі зрушення у виробничій інформації, системах управління якістю та управління ризиками.

У попередніх повідомленнях описано можливості застосування принципів дизайну експерименту при вивченні впливу якісних та кількісних фракторів на технологічні показники лікарських фрорм на етапі розробки та оптимізації складу таблетованих лікарських засобів (Л3), а також використання штучних нейронних мереж при розробці таблетованих засобів із модисрікованим вивільнення [1-3]. Новітній етап технології Л3, в теоретичному і практичному розумінні,

ISSN 2312-0967. Pharmaceutical review. 2021. № 2 
передбачає забезпечення якості Лз, а не контроль. Якість спершу моделюється, а потім вбудовується у ЛЗ шляхом належного вибору АФІ, лікарської фрорми, допоміжних речовин, технології, систем упаковки, умов зберігання та ін. Вбудовування якості у Лз при його розробці вимагає наукових знань і здійснення комплексу досліджень. «Якість шляхом розробки» (Quality by design - QbD) - науково обґрунтований підхід, який ґрунтується на надійних наукових даних та управлінні ризиками для якості, вдосконалює розуміння процесу та його контроль за рахунок зменшення можливих його варіацій та надає можливість управління технологічним процесом виробництва конкретної лікарської фрорми. Вперше термін QbD було визначено кілька десятиліть тому доктором Джозефом М. Джураном (Joseph M. Juran), який наголосив на важливості дизайну розробки лз та виробничого процесу для досягнення певної, заздалегідь визначеної, якості [4-6].

QbD передбачає аналіз та контроль усіх можливих ризиків, допускаючи, що кожен технологічний крок процесу є джерелом ризику чи зміни. В останні роки концепція «якість шляхом розробки» набуває все більшого значення при створенні та промисловому виробництві Л3. QbD рекомендується Управлінням 3 контролю за продуктами та ліками (Food and Drug Administration - FDA) та Європейським агентством із лікарських засобів (European Medicines Agency EMA) як один із методів покращення якості фрармацевтичної продукції [7].

Мета роботи - аналіз та систематизація даних літератури щодо використання підходу QbD при розробці складу та технології таблетованих лз.

Матеріали і методи. У роботі використано методи інфрормаційного пошуку та аналізу отриманих даних літератури щодо використання підходу «якість шляхом розробки» при проведенні досліджень зі створення таблетованих ЛЗ.

Результати й обговорення. На сьогодні $€$ декілька рекомендаційних документів, зокрема настанови ICH Q8 «Фармацевтична розробка», ICH Q9 «Управління ризиками для якості» та ICH Q10 «Фармацевтична система якості», які в комплексі із використанням процесно-аналітичної технології (Process analytical technology - РАT), пояснюють підхід QbD [6, 8, 9]. Створення ЛЗ чи медичних виробів із використанням QbD забезпечує якість, контролює ризики і $є$ невід'ємною складовою розробки лз.

Настанова ICH Q8 «Фармацевтична розробка» регламентує положення системного підходу до фрармацевтичної розробки лз, визначені застосуванням наукових підходів та управлінням ризиками щодо якості засобу та виробничого процесу. Ця настанова рекомендується для побудови та оцінки фрармацевтичних систем якості, які використовують при розробці та виробництві ЛЗ впродовж його життєвого циклу [6].
Принципи настанов ICH Q9 «Управління ризиками якості» та Q10 «Фармацевтична система якості» були сорормовані на основі твердження, що якість ЛЗ необхідно закладати на етапі його фрармацевтичної розробки $[8,9]$.

Тому метою настанови ICH Q9 є системний підхід до управління ризиками для якості на етапах: розробка, виробництво, лабораторний контроль, упаковка та маркування, а також діяльності щодо перевірки та їхньої оцінки. Метою настанови «Управління ризиками якості» $€$ форомування єдиного розуміння щодо управління ризиками, включно, які охоплюють продукцію, процеси та обладнання, також оцінюють ризики, що впливають на надійність фрармацевтичної системи якості, та здійснюють контроль, пов'язаний із зменшенням ризиків [8]. Основними принципами даної настанови $є$ врахування наукових даних та інтересів пацієнтів при оцінюванні ризику для якості, а також відповідність рівня фрормування процесу управління ризиками рівню власне ризику. Настанова конкретно надає вказівки щодо принципів та деяких інструментів управління ризиками для якості, які можуть давати можливість приймати більш ефективні та послідовні рішення щодо якості субстанцій та ЛЗ впродовж усього життєвого циклу, що ґрунтуються на оцінці ризиків $[8,10]$.

Настанова ICH Q10 «Фармацевтична система якості» ґрунтується на концепціях якості Міжнародної організації зі стандартизації (International Organization for Standardization - ISO) та містить відповідні норми належної виробничої практики (Good Manufacturing Practice - GMP). Настановою ICH Q10 визначено рекомендації щодо системи управління якістю фрармацевтичної промисловості для підвищення якості та покращення доступності Лз. Елементами фрармацевтичної системи якості є: система моніторингу функціональних характеристик процесу та якості продукції; система коригувальних та запобіжних дій (Corrective and preventive action - CAPA); система управління змінами; аналіз керівництвом есрективності процесу та якості продукції [9].

Використання РАТ як системи планування, аналізу та контролю виробництва шляхом визначення критичних показників та характеристик вихідних компонентів, матеріалів і процесів забезпечує якість готового ЛЗ. РАТ ґрунтується на двох основних компонентах: розумінні наукових та інженерних принципів, які стосуються виробничого процесу, та виявленні змінних, які впливають на якість продукції [11].

Метою підходу QbD є поглиблене розуміння рецептурних та технологічних змінних, їхній впливу, а також взаємозв'язку між ними для отримання Лз зі стабільними бажаними характеристиками [12, 13]. $\mathrm{QbD}$ допомагає встановити критичні показники якості (Critical quality attribute - CQA), критичні параметри матеріалу (Critical material attribute - CMA) та критичні параметри процесу (Critical process parameter -

ISSN 2312-0967. Фармацевтичний часопис. 2021. № 2 
(РP), що можуть бути змінені для отримання л3 із заздалегідь визначеними показниками якості.

Підхід QbD включає кілька ключових етапів (рис. 1), першим із яких є визначення цільового профрілю якості Л3 (Quality target product profile - QTPP) - складання резюме, а саме визначення основних показників якості Л3, яких потрібно досягнути для забезпечення необхідної якості досліджуваного препарату з урахуванням його безпечності та ефективності [14]. Наприклад, типовий QTPP для твердої пероральної лікарської фрорми включає характеристику Л3, випробування на однорідність, домішки, стабільність, розпадання та інші показники [15]. Міжнародне товариство інженерів фрармацевтичної промисловості (ISPE) та Інститут досліджень якості продукції (PQRI) називає QTPP як профріль фрармацевтичного цільового продукту.

FDA опублікувала настанову, що охарактеризовує цільовий профріль препарату (Target product profile TPP) [16], в якому основна увага приділяється споживачу (пацієнту) та маркуванню ЛЗ. QTPP є підгрупою ТРP і більше орієнтований на хімічні, технологічні та аналітичні аспекти. Наприклад, показник таблеток «міцність» може бути включений як параметр контролю процесу, але може бути не включеним до QTPP. Крім того, якщо розмір частинок є критичним параметром розчинення ЛЗ у твердій лікарській фрормі для перорального застосування, то QTPP повинен включати час розчинення, але не розмір частинок $[17,18]$ Q QTPP $є$ основою дизайну для розробки л3 i розробляється з урахуванням мети дослідження та цілей, яких потрібно досягти. QTPP може бути як перспективним, описуючи цілі та завдання для роботи команди розробників, так і динамічним, оскільки може бути оновленим або переглянутим на різних етапах розробки лз, адже оновлена інорормація та результати отримують у процесі розробки Л3 [19]. Варто зауважити, що для генеричних препаратів підтвердження біоеквівалентності повинно бути включено до складу QTPP. Таким чином, цільовий профріль препарату не $є$ лише специфікацією на лЗ та включає характеристики ЛЗ щодо галузі його застосування, лікарської фрорми та шляху ії̈ введення, дозування та критеріїв якості [20].

Другим етапом QbD є проведення оцінки ризиків, щоб визначити компоненти складу, матеріали або параметри процесу, що можуть потенційно вплинути на CQA з погляду його фрізичних, хімічних, біологічних або мікробіологічних властивостей/характеристик, які слід прямо чи опосередковано контролювати для забезпечення якості продукції [21]. CQA також включають властивості вихідних компонентів, які можуть впливати на есрективність ЛЗ або на його технологію. Прикладом цього може бути розподіл частинок лікарської речовини за їхнім розміром або насипна густина, що впливатимуть на технологічні параметри виробництва Л3. Подібним чином розчинення лікарської форми з контрольованим вивільненням залежить від розміру частинок полімеру та міцності таблеток. У даних прикладах CQA можна вважати роз-

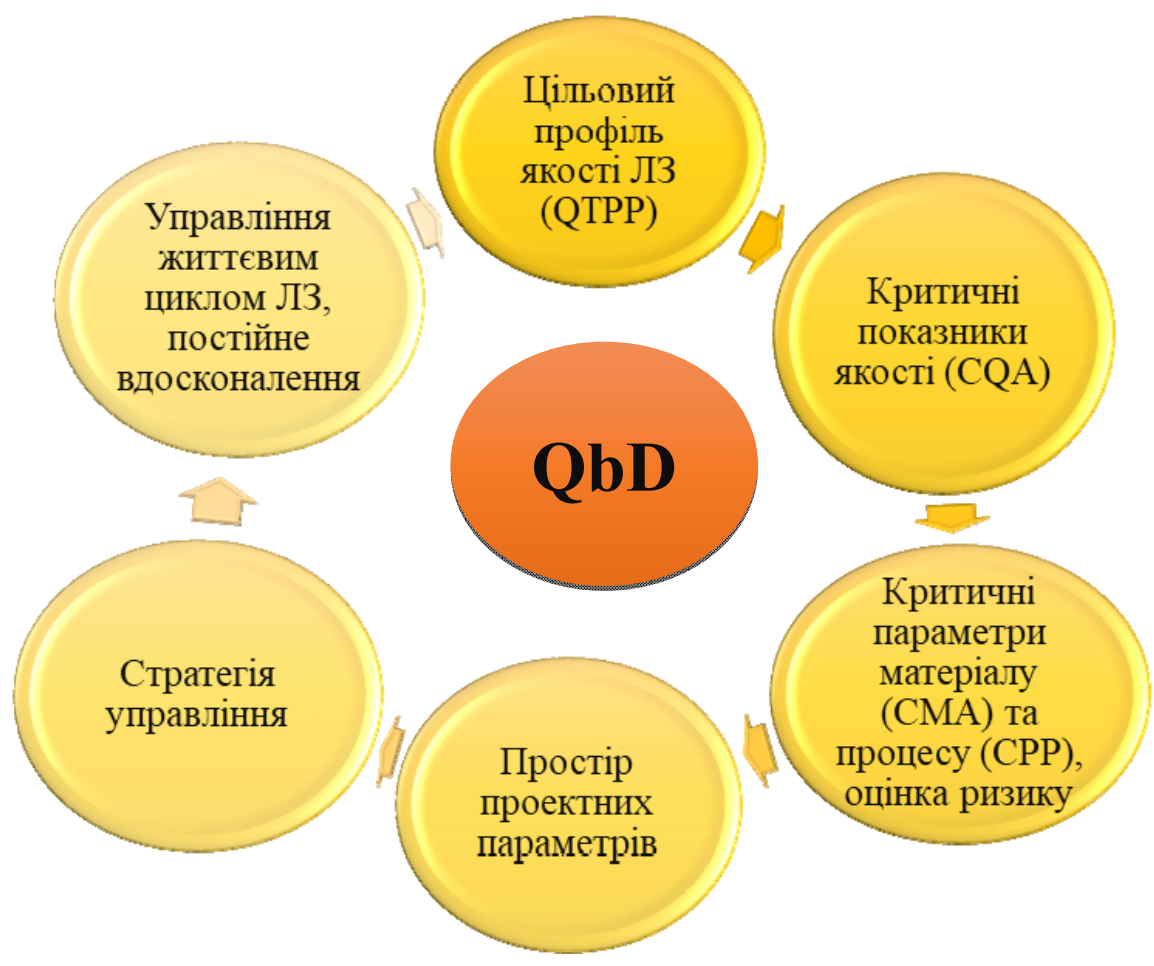

Рис. 1. Концепція QbD.

ISSN 2312-0967. Pharmaceutical review. 2021. № 2 


\section{Reviews}

поділ частинок лікарської речовини за їхнім розміром та міцність таблетованої лікарської форми [22].

Третім етапом QbD є вивчення впливу таких змінних параметрів, як компоненти складу (активні фрармацевтичні інгредієнти (АФІ) та допоміжні речовини), параметри процесу на CQA готового ЛЗ з метою визначення того, які з досліджених показників $€$ критичними параметрами матеріалу (СМА), а які є критичними параметрами процесу (СРР). СРР встановлюються шляхом аналізу того, наскільки будь-які зміни процесу можуть вплинути на якість препарату $[4,15]$.

Четвертим етапом $€$ створення простору проектних параметрів (Design space), який узагальнює взаємозв'язок між вхідними даними процесу та критичними показниками, та може бути описаний, наприклад, у вигляді діапазонів певних характеристик або як фрунція, що залежить від часу. Відповідно до ICH Q8, простір проектних параметрів - багатовимірна комбінація вхідних змінних (наприклад, параметрів матеріалу чи допоміжних речовин) та параметрів процесу, при яких було доведено забезпечення якості Л3 (рис. 2). Розуміючи суть «простору проектних параметрів», можна визначити і показати межі, в яких повинен здійснюватися процес, щоб з упевненістю виробляти готовий лз із необхідною якістю $[6,23,24]$.

При розробці складу таблеток, що диспергуються в ротовій порожнині, на основі паліперидону гідрохлориду визначено, що кількості мікрокристалічної целюлози марки Avicel PH 102 та Indion 234 є критичними параметрами для досягнення бажаного QTPP, та мають визначальний вплив на такі критичні показники якості (CQAs), як час розпадання та вивільнення АФІ із лікарської фрорми. Враховуючи вимоги до якості Л3, критеріями якості обрано час розпадання - до 30 с та вивільнення АФІ із ЛЗ - не менше $90 \%$ впродовж 15 хв. Простір проектних параметрів (жовтий колір на рисунку 3, А) відображає діапазон, в межах якого отримують оптимальні показники вивільнення АФІ (> 90 \%). Оптимізований склад розроблених таблеток характеризувався такими фрармакотехнологічними показниками: час розпадання -

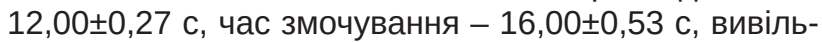

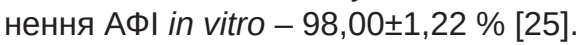

Використовуючи підхід «Якість шляхом розробки» розроблено склад оральних ліофілізатів на основі ібупрофену для застосування в педіатрії. У процесі дослідження вибрано CMAs, CQAs, запропоновано QTPP. Встановлено, що визначальний вплив на показники розпадання та міцності проявляють формоутворюючий та біоадгезивний компоненти, наповнювачі. Розроблений простір проектних параметрів показує діапазон, в межах якого розроблена лікарська форма характеризується оптимальними значеннями розпадання (до 5 хв) та міцності. На підставі реалізації підходу QbD визначено оптимальний склад допоміжних речовин у розроблених оральних ліофілізатах на основі ібупрофену: натрію альгінат - 0,7 \%, гідроксипропілметилцелюлоза (ГПМЦ) - 0,17 \%, трегалоза - $10 \%$ (рис. 3, Б) [26].

Завершальним етапом QbD є розробка та впровадження стратегії управління (Control Strategy) 3 метою забезпечення постійного безперервного вдосконалення (Continual improvement) [4].

У процесі реалізації підходу «Якість шляхом розробки» можуть використовувати такі інструменти, як дизайн експерименту (Design of Experiments - DoE),

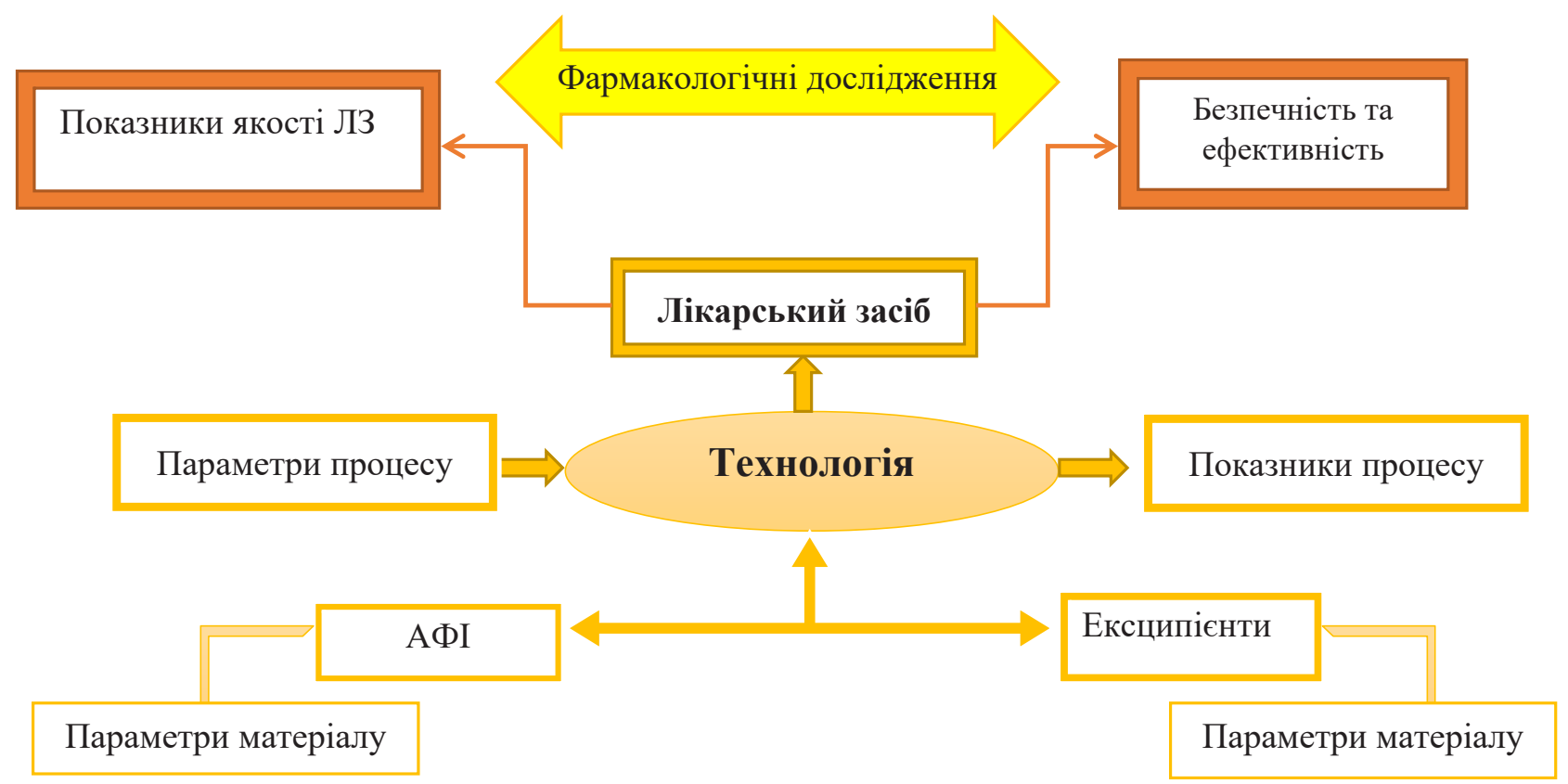

Рис. 2. Характеристика концепції «Простір проектних параметрів».

ISSN 2312-0967. Фармацевтичний часопис. 2021. № 2 


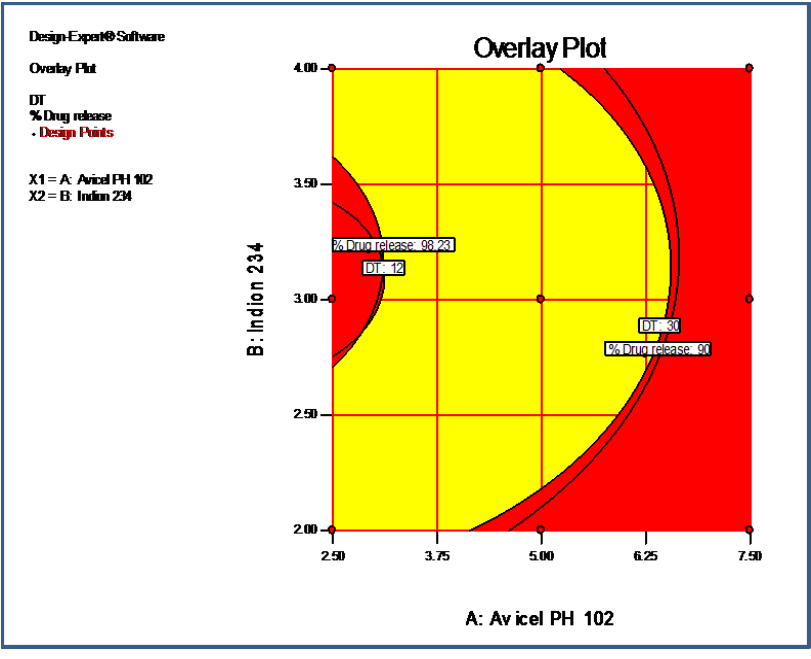

A

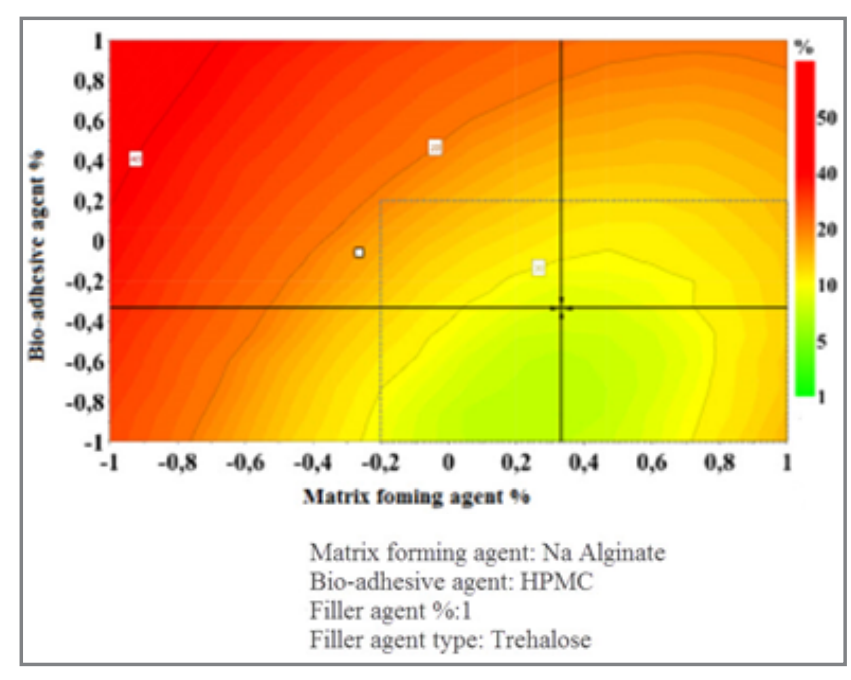

Б

Рис. 3. Простір проектних параметрів.

А - для розробки складу таблеток, що диспергуються в ротовій порожнині, на основі паліперидону гідрохлориду

[25]; Б - для розробки оральних ліофрілізатів на основі ібупрофену [26].

оцінка ризиків та РАТ, проте їхнє застосування не є обов'язковим [27].

Також важливою особливістю при використанні підходу «Якість шляхом розробки» $є$ визначення ризику, що є поєднанням ймовірності настання шкоди та її тяжкості, оскільки саме ризик є визначальним для впливу вхідної змінної на методи або процеси. За оцінкою ризику можна розпізнати критичні ознаки, які вплинуть на кінцеву якість лз.

Управління ризиками - спільна відповідальність підрозділів з якості, розвитку бізнесу, інженерингу, регуляторних питань, виробничих операцій, збуту та маркетингу, юридичного, статистичного та клінічного відділів фрармацевтичного підприємства [8].

Комітет виробничих технологій (МTC) Інституту досліджень якості продукції (PQRI) підготував загальний перелік інструментів передового досвіду управління ризиками та низку прикладів програм управління ризиками, які на сьогодні використовують великі фрармацевтичні виробники та регуляторні органи [28], а також описані в настанові ICH Q9 [8]:

1) аналіз характеру наслідків відмов (Failure Mode Effects Analysis -FMEA);

2) аналіз характеру, наслідків та критичності відмов (Failure Mode, Effects and Criticality Analysis FMECA); FTA);

3) аналіз дерева помилок (Fault Tree Analysis -

4) аналіз експлуатаційної безпеки та критичні контрольні точки (Hazard Analysis and Critical Contro Points - HACCP);

5) аналіз експлуатаційної безпеки та працездатності (Hazard Operability Analysis - HAZOP);

6) попередній аналіз експлуатаційної безпеки (Preliminary Hazard Analysis - PHA);
7) ранжування та фрільтрація ризиків (Risk ranking and filtering).

Основними допоміжними інструментами управління ризиками $є$ блок-схеми, контрольні карти, причинно-наслідкові діаграми (діаграми Ішикаві). До допоміжних статистичних методів, що широко використовують у фрармацевтичній промисловості, належать контрольні карти (наприклад, приймального контролю, кумулятивних сум), гістограми, DoE, діаграми розсіювання, діаграми стратисрікації (метод розшарування), діаграми Парето та інші $[4,8,28]$.

Одним із інструментів для оцінки ступеня ризику, що найчастіше застосовують при розробці таблетованих Л3, є FMEA, який зазвичай використовують для систематичної оцінки потенційного ступеня ризику для кожного робочого параметра та для визначення пріоритету діяльності, наприклад, експериментів, необхідних для розуміння впливу цих параметрів на загальну продуктивність процесу [8, 26, 29].

Для того, щоб вивчити взаємозв'язок між СМА та CPP, та їхній вплив на CQA в математичній (статистичній) фрормі, використовують стратегію проектування експерименту. Одним із невід'ємних інструментів QbD при розробці оптимізованих продуктів та процесів $€$ DoE, застосування якого полягає у використанні експериментальних математичних моделей. Інформацію, пов'язану з математичними моделями, застосовують незалежно та інтегровано на етапі розробки Л3 [30].

DoE характеризується як багатовимірна комбінація та взаємодія вхідних змінних (наприклад, параметрів матеріалу) та параметрів процесу, які є важливими для забезпечення якості. Науковці з фрармацевтичної розробки почали використовувати для оптимізації виробництва автоматизоване проектування та моделювання

ISSN 2312-0967. Pharmaceutical review. 2021. № 2 


\section{Reviews}

процесів. 3 цією метою можуть застосовувати незалежні простори проектних параметрів для однієї або декількох одиничних операцій або ж єдиний проектний простір для декількох операцій. Наприклад, вплив зміни допоміжної речовини на розподіл частинок за розміром, схильність до втрати однорідності суміші можуть бути включені в план експерименту [31].

Використовуючи підхід «Якість шляхом розробки», розроблено склад гранул напроксену, вкритих кишковорозчинною оболонкою в псевдозрідженому шарі, запропоновано простір проектних параметрів, який складається із областей перекривання діапазонів для декількох CQAs. Значення кислотостійкості (\%) та комулятивного вивільнення АФІ (\%) з розробленого засобу обрано як CQAs, запропоновано відповідні критерії: для кислотостійкості - 10 \%, для вивільнення - 80 \%. На підставі діаграм Парето та вибраного методу оптимізації складу встановлено значущість за впливом таких фракторів, як кількості триетилцитрату $\left(\mathrm{X}_{1}\right)$, гліцерилмоностеарату $\left(\mathrm{X}_{2}\right)$ та збільшення маси покриття $\left(X_{7}\right)$, взаємозв'язок їх між собою та із визначеними CQAs. Розроблено простір проектних параметрів, що складається 3 області (жовтий колір) перекривання діапазонів, притаманних двом CQAs, 3 використанням у складі розроблених гранул гліцерилмоностеарату в кількості $3 \%$ (рис. 4, А) та $10 \%$ (рис. 4, В), накладені області одна на другу, зображені на рисунку 4, C, задовільняють вибрані критерії показників якості, при цьому кількість гліцеририлмоностеарату може бути від 3 до $10 \%$, значення $\mathrm{X}_{1}$ та $\mathrm{X}_{7}$ залишаються змінними. Помаранчева область, наведена на рисунку 4, D, відображає простір проектних параметрів для розробки гранул напроксену з належними показниками якості, при цьому збільшення маси покриття та кількість триетилцитрату обмежується значеннями даної області [32].

Для проектування експерименту доступні такі математичні моделі, як повний фракторний експеримент, дробний факторний експеримент, метод випадкового балансу, плани Плакета-Бермана, симетричні ортогональні композиційні плани, плани Бокса-Бенкена, плани Хартлі [33].

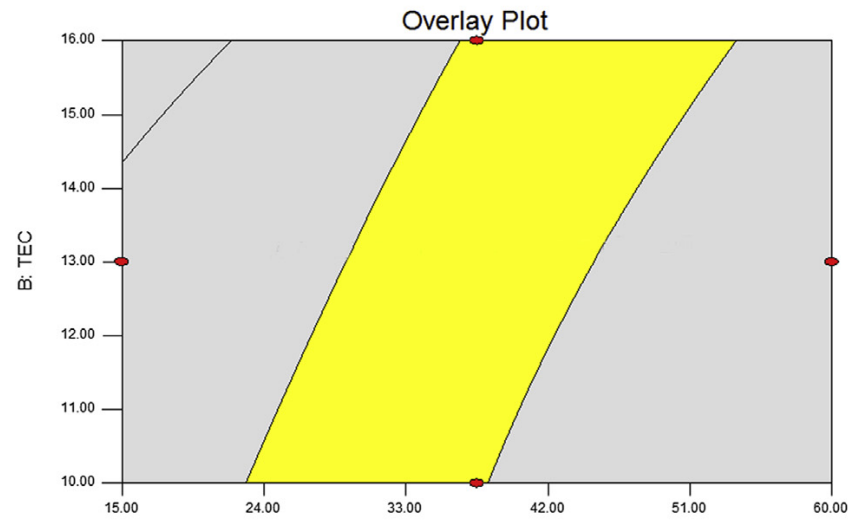

A: coating weight gain

A

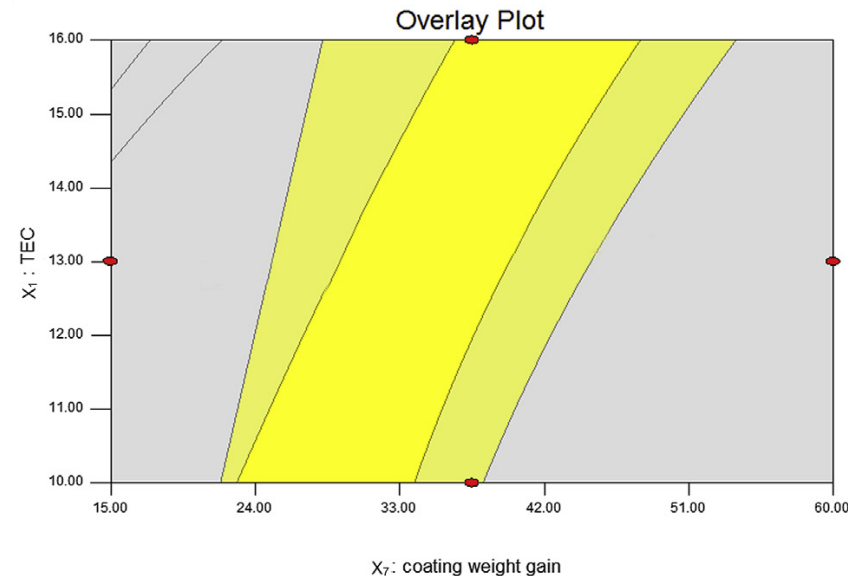

C

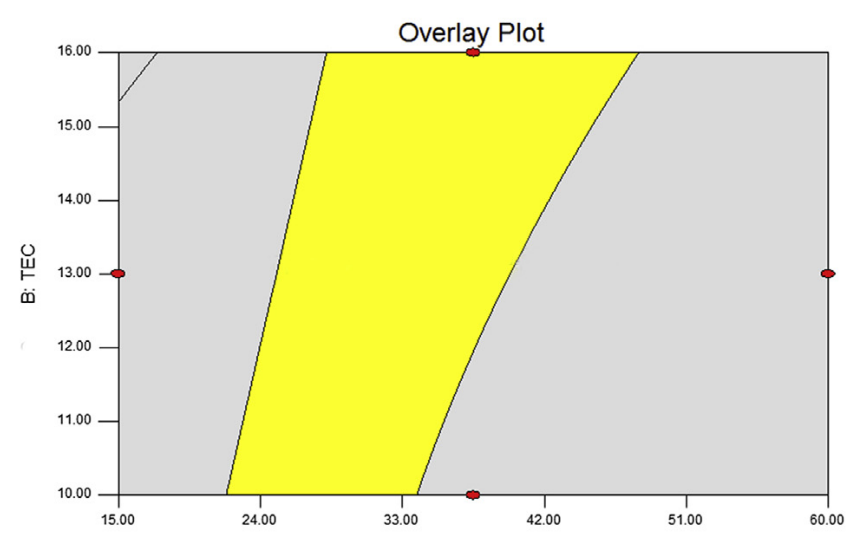

A: coating weight gain

b

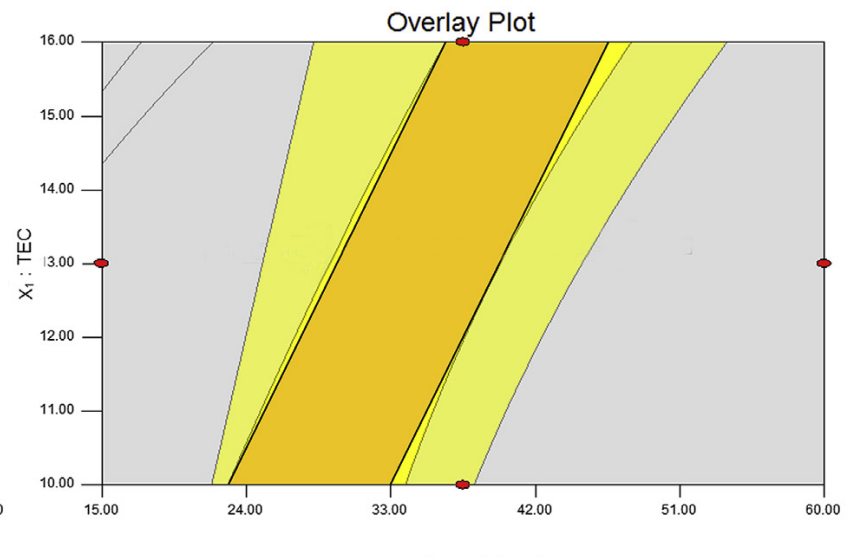

$x_{7}$ : coating weight gain

$\mathrm{D}$

Рис. 4. Простір проектних параметрів для розробки гранул напроксену, вкритих кишковорозчинною оболонкою, складається з областей перекривання діапазонів для декількох CQAs, з використанням гліцерилмоностеарату в кількості 3 \% (A) та 10 \% (B); теоретична область (C) та область застосування (D) [32].

ISSN 2312-0967. Фармацевтичний часопис. 2021. № 2 
Повний фракторний експеримент використано для вивчення впливу фракторів рецептури на фрармакотехнологічні властивості таблеток, в якому незалежними зміними були кількості зв'язуючого агента та дезінтегранта, тоді як залежною змінною було вивільнення АФІ (ітоприду гідрохлориду) 3 лікарської форми. Такий мультидисциплінарний підхід $є$ вигідним, оскільки вдосконалення виробничого процесу може бути здійснено в попередньо затвердженому просторі, що зменшує кількість можливих варіацій після маркетингових досліджень. Даний підхід ґрунтується на оцінці ризику, який базується на своєчасному контролі якості, а не на остаточному випробуванні готового Л3 [1, 2, 34].

Дизайн експерименту також застосовують для дослідження фрармацевтичного процесу, можливими фракторами є показники матеріалу (наприклад, розмір частинок) та параметри процесу (наприклад, швидкість та час), тоді як критичними показниками якості $\epsilon$ такі вихідні показники ЛЗ, як однорідність порошкової суміші, міцність таблетки, товщина тощо. Результати DoE можуть допомогти визначити оптимальні умови, критичні фрактори, які найбільше впливають на CQAs, та ті чинники, які не проявляють вагомого впливу, а також існування можливих взаємодій та синергій між факторами. 3 огляду на прийнятий діапазон CQA, можна визначити простір проектних параметрів. Однак при розгляді масштабу може знадобитися додаткова експериментальна робота, щоб підтвердити, що модель, створена в зменшеному варіанті, $є$ прогнозованою у реальному масштабі [35].

Факторіальний дизайн використовували для оцінки фракторів, що впливають на хімічну стабільність рапаміцину у твердих лікарських фрормах. Вплив чотирьох параметрів процесу та складу (швидкість розпилення розчину етанолу, умови сушіння, міцність та вміст ГПМЦ) оцінювали з погляду початкової якості таблеток, використовуючи фракторний експеримент. Використання підходу QbD та фракторіального експерименту є економічно вигідним способом отримання максимального обсягу інформації за короткий проміжок часу, що особливо важливо у дослідженнях, які включають безліч різних фракторів та їхньої взаємодії [36].

У дослідженнях з розробки оптимального складу таблеток метформіну гідрохлориду (вміст АФІ 750 мг) 3 пролонгованим вивільненням використано план Бокса-Бенкена. За допомогою комп'ютерної методики оптимізації, основаної на методології поверхні відповіді (response surface methodology -RSM) з використанням поліноміального рівняння, запропонована трисракторна трирівнева оптимізація із використанням комбінації ГПМЦ, полівінілпіролідону марки К30 (ПВП К30) та гліцерилбегенату. Оптимізований склад було отримано 3 такими кількостями допоміжних речовин: 165 мг ГПМЦ, 40 мг ПВП К30 та 22,5 мг гліцерилбегенату [37].
Підхід «Якість шляхом розробки» було використано при отриманні біоадгезивних мікросорер леводопи. Трифракторний трирівневий план експерименту 3 методологією поверхні відгуку (RSM) був застосований для оцінки основного ефекту та взаємодії декількох незалежних змінних досліджуваного складу л3, а саме: полімер $\left(\mathrm{X}_{1}\right)$, співвідношення ГПМЦ та карбомеру Carbopol 934P $\left(\mathrm{X}_{2}\right)$ та швидкість перемішування $\left(\mathrm{X}_{3}\right)$. Залежними змінними вибрано такі показники: індекс набрякання $\left(\mathrm{Y}_{1}\right)$, однорідність вмісту $\left(\mathrm{Y}_{2}\right)$, відсоток вивільнення АФІ $\left(Y_{3}\right)$, розмір мікросорер $\left(Y_{4}\right)$ та відсоток біоадгезії $\left(Y_{5}\right)$. Для вивчення впливу кожного із досліджуваних фракторів на показники якості розроблених мікроссрер леводопи була отримана відповідна математична залежність. Дане дослідження продемонструвало потенціал застосування QbD в обґрунтуванні впливу змінних складу на показники якості складів мікросорер леводопи [38].

При розробці складу ородисперсних таблеток методом прямого пресування, що містять тверду дисперсію ацеклофенаку 3 ранітидину гідрохлоридом, також використано підхід QbD. До розроблених складів входили поєднання з полімерами, поверхнево активними речовинами та регуляторами $\mathrm{pH}$ у різних співвідношеннях. Під час розробки даних таблеток було визначено перелік CQA (наприклад, міцність, крихкість) та визначено QTPP. Дисперсію ацеклофенаку використано як статистичний фрактор для вибору виду розчинника та твердої дисперсії, а також при оптимізації - для вибору дезінтегранта та його кількості у складі таблеток. Регресійний аналіз виявив значний вплив поліноміальних фракторів при розробці складу досліджуваних таблеток. Було визначено, що міцність та крихкість є найважливішими фракторами, що впливають на час розпадання та вигляд профріля вивільнення АФІ із лікарської фрорми. Дані дослідження вкотре підтвердили, що застосування підходу «Якість шляхом розробки» $є$ еорективним для розуміння якості та оптимізації складу таблетованих Л3, зокрема, на прикладі ородисперсних таблеток, що містить тверду дисперсію ацеклофенаку з ранітидину гідрохлоридом [39].

Переваг методу QbD надзвичайно багато, проте використання даного підходу на практиці включає багато математичних та статистичних тонкощів. На сьогодні, завдяки наявності сучасних технологій, можна використовувати спеціально розроблені програми, які є комерційно доступними для проведення досліджень із використанням підходу QbD в промислових умовах. Комп'ютерні програми, доступні для оптимізації DoE, включають: Design-Expert, MODDE, Unscrambler, JMP, Statistica, Minitab та інші. Для управління ризиками якості із використанням діаграм Ішікаві, матриць REM та FMEA під час досліджень оцінки ризику тощо можна використовувати таке програмне забезпечення, як Minitab, Risk, Statgraphics, FMEA-Pro, iGrafx та інші.

ISSN 2312-0967. Pharmaceutical review. 2021. № 2 
Висновки. Використання підходу QbD у фрармацевтичній промисловості можна узагальнити такими перевагами: основна увага приділяється безпеці та ефективності Л3 чи медичних виробів, узагальнюється технологічне розуміння фрармацевтичного процесу та методів, здійснюється наукове обґрунтування оцінки ризиків, визначення критичних показ- ників якості та аналіз їхнього впливу на кінцеву якість розробленого засобу. Концепція QbD допомагає уникнути витрат, пов'язаних зі змінами після їх затвердження.

Конфрлікт інтересів: відсутній.

Conflict of interest: authors have no conflict of interest to declare.

\section{EXPERIMENTAL DESIGN IN RESEARCH AT THE CREATION OF TABLET MEDICINES. MESSAGE 4. USING THE METHOD "QUALITY BY DESIGN" (QbD) IN OPTIMIZING THE COMPOSITION AND TECHNOLOGY OF TABLET DRUGS}

\section{T. A. Hroshovyi, B. V. Pavliuk, M. B. Chubka, M. B. Demchuk, Yu. V. Nayda}

I. Horbachevsky Ternopil National Medical University ${ }^{1}$

PJSC "Farmak"

hrochovuy@tdmu.edu.ua

The aim of the work. Analysis and systematization of literature data on the use of the approach Quality by Design in order to develop the optimal composition and technology of tablet drugs.

Materials and Methods. The methods of information search, analysis of scientific literature data on the possible application of the approach Quality by Design and its practical use in the development of the composition and technology of tablet drugs are used.

Results and Discussion. The work describes the general concept of the approach Quality by Design in pharmaceutical technology of medicines. Data on the practical application of this approach in the development of the composition and technology of tableted drugs, their optimization.

Conclusions. Quality by Design is an important and widely used technique in the development of medicines. During using the Quality by Design approach, the main attention is paid to the safety and efficacy of the drug, the technological understanding of the pharmaceutical process and applied methods are generalized, the scientific substantiation of risk assessment, determination of critical quality indicators, and analysis of their impact on the final quality of the developed product.

Key words: experimental design; quality by design; mathematical experiment planning; tablets.

\section{ДИЗАЙН ЭКСПЕРИМЕНТА ПРИ ПРОВЕДЕНИИ ИССЛЕДОВАНИЙ ПО СОЗДАНИЮ ТАБЛЕТИРОВАННЫХ ЛЕКАРСТВЕННЫХ СРЕДСТВ. СООБЩЕНИЕ 4. ИСПОЛЬЗОВАНИЕ МЕТОДА «КАЧЕСТВО ПУТЕМ РАЗРАБОТКИ» (QbD) ПРИ ОПТИМИЗАЦИИ СОСТАВА И ТЕХНОЛОГИИ ТАБЛЕТИРОВАННЫХ ЛЕКАРСТВЕННЫХ СРЕДСТВ}

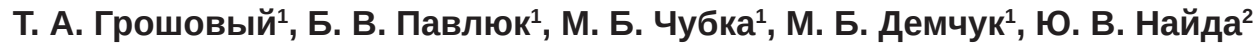

Тернопольский национальный медицинский университет имени И. Я. Горбачевского МОз Украины ${ }^{1}$ ЧАО «Фармак»²

hrochovuy@tdmu.edu.ua

Цель работы. Анализ и систематизация данных литературы по использованию подхода «Качество путем разработки» (Quality by Design) с целью разработки оптимального состава и технологии таблетированных лекарственных средств.

Материалы и методы. В работе использованы методы информационного поиска, анализа данных научной литературы о возможном применении подхода «Качество путем разработки» и практического его использования при разработке состава и технологии таблетированных лекарственных средств.

Результаты и обсуждение. В работе описана общая концепция подхода «Качество путем разработки» в фрармацевтической технологии лекарственных средств. Приведены данные по практическому применению данного подхода при разработке состава и технологии таблетированных лекарственных средств, их оптимизации.

Выводы. «Качество путем разработки» является важной и широко используемой стратегией при разработке лекарственных средств. При использовании данного подхода основное внимание уделяется безопасности и

ISSN 2312-0967. Фармацевтичний часопис. 2021. № 2 
эфрфективности лекарственного средства, обобщается технологическое понимание фрармацевтического процесса и применяемых методов, осуществляется научное обоснование оценки рисков, определение критических показателей качества и анализ их влияния на конечное качество разработанного средства.

Ключевые слова: дизайн эксперимента; качество путем разработки; математическое планирование эксперимента; таблетированные лекарственные средства.

\section{Список бібліографрічних посилань}

1. Дизайн експерименту при проведенні досліджень зі створення таблетованих лікарських засобів (Повідомлення 1) / Т. А. Грошовий та ін. Фармацевт. часоп. 2020. № 2. С. 101-110.

2. Дизайн експерименту при проведенні досліджень зі створення таблетованих лікарських засобів (Повідомлення 2. Дизайн експерименту при дослідженні впливу кількісних фракторів на етапі оптимізації складу та технології таблетованих лікарських засобів) / Т. А. Грошовий та ін. Фармацевт. часоп. 2020. № 3. С. 70-79.

3. Дизайн експерименту при проведенні досліджень зі створення таблетованих лікарських засобів (Повідомлення 3. Використання штучних нейронних мереж у дизайні експерименту із розробки складу і технології таблетованих лікарських засобів із модифрікованим вивільненням) / Т. А. Грошовий та ін. Фармацевт. часоп. 2021. № 1. С. 76-85.

4. Pharmaceutical Quality by Design: A Practical Approach. Editor(s): Walkiria S. Schlindwein, Mark Gibson. John Wiley \& Sons Ltd. 2018; $368 p$.

5. Rayaprolu B. M. Quality by design: A brief introduction. Journal of Pharmacovigilance. 2015. No 3 (4). P. e142.

6. СТ-Н 42-3.0:2011. Настанова. Лікарські засоби. Фармацевтична розробка (ICH Q8). Вид. офріц. Київ, м03 України, 2011. 42 с.

7. QbD implementation and post approval lifecycle management (PALM). E. Ohage, R. Iverson, L. Krummen, et al. Biologicals. 2016. Iss. 44. P. 332-340.

8. СТ-Н 42-4.2:2011. Лікарські засоби. Управління ризиками для якості (ICH Q9). Вид. офріц. Київ, МО3 України, 2011. 30 с

9. СТ-Н 42-4.3:2011. Лікарські засоби. Фармацевтична система якості (ICH Q10). Вид. офріц. Київ, МОЗ України, 2011. 30 с

10. Application of quality by design to different aspects of pharmaceutical technologies. D. M. Patwardhan, S. S. Amrutkar, T. S. Kotwal et al. Int. J. Pharm. Sci. Res. 2017. No. 8. Iss. 9. P. 3649-3662.

11. Dipen Gaykar, Saurabh C. Khadse. A review on analytical quality by design. Int. J. Pharm. Sci. Rev. Res. 2017. No. 44. Iss. 2. P. 96-102.

12. Shirsat A. E., Chitlange S. S. Application of quality by design approach to optimize process and formulation parameters of rizatriptan loaded chitosan nanoparticles. J Adv. Pharm. Technol. Res. 2015. No. 6. Iss. 3. P. 88-96.

13. Optimization of a pharmaceutical freeze-dried product and its process using an experimental design approach and innovative process analyzers. T. R. De Beer, M. Wiggenhorn, A. Hawe et al. Talanta. 2011. Iss. 83. P. 1623-1633.
14. Mogal V. A review on quality by design. Pharm. Biol. Eval. 2016. No. 3. P. 313-319.

15. Arijit Gandhi, Chandrani Roy. Quality by design (QbD) in pharmaceutical industry: Tools, perspectives and challenges. Pharma Tutor. 2016. No. 4. Iss. 11. P. 12-20.

16. FDA CDER. Draft guidance for industry and review staff. Target product profile-strategic development process tool, March 2007. Access mode : http://www. ncai-cc.ccf.org/skills/documents/U.S.\%20FDA\%20 Target\%20Product\%20Profile\%20Guidance\%20Document\%20(2007).pdf

17. Quality by design for generic drugs. L. X. Yu, R. Lionberger, M. C. Olson et al. Pharm. Tech. 2009. Iss. 33. P. 122-127.

18. Patil A. S., Pethe A. M. Quality by design (QbD): A new concept for development of quality pharmaceuticals. IJPQA. 2013. No. 4. P. 13-19.

19. Gupta Anuj, Neeraj Kumar Fuloria. Short review on quality by design: A new era of pharmaceutical drug development. Int. J. Drug Dev. Res. 2012. No. 4(3). P. 19-26.

20. Aksu B., Mesut B. Quality by design (QbD) for pharmaceutical area. J. Fac. Pharm. Istanbul. 2015. Iss. 45. P. 233-251.

21. Mesut B., Aksu B., Özsoy Y. The place of drug product critical quality parameters in Quality by Design (QBD). Turk. J. Pharm. Sci. 2015. No. 12 (1). P. 75-92.

22. A quality by design (QbD) study on enoxaparin sodium loaded polymeric microspheres for colonspecific delivery. D. Hales, L. Vlase, S. A. Porav et al. Eur. J. Pharm. Sci. 2017. Iss. 100. P. 249-261.

23. Kumar Deepak, Ancheria Rahul, Shrivastava Saumya, Soni Shankar Lal, Sharma Vandana. Review on pharmaceutical quality by design (QbD). Kumar Deepak, Ancheria Rahul, Shrivastava Sau-mya et al. Asian JPRD. 2019. Iss. 7 (2). P. 78-82.

24. Design space approach for preservative system optimization of an anti-aging eye fluid emulsion. F. R. Lourenço, F. L. Francisco, M. R. S. Ferreira et al. J Pharm Pharm Sci. 2015. Iss. 18 (2). P. 551-561.

25. Formulation and evaluation of Paliperidone $\mathrm{HCl}$ mouth dissolving tablet by QbD approach. Santosh D. Borde, Sadhana R. Shahi, Kiran V. Kale et al. Pharm. Biol. Eval. 2016. Iss. 6. Vol. 3. P. 528-540.

26. QbD approach in the development of oral lyophilisates with ibuprofen for paediatric use. S. Suciu, S. Iurian, C. Bogdan et al. Farmacia. 2018. Vol. 66 (3). P. 514-523.

27. Formulation design of the oral disintegrating tablets including alfuzosin hydrochloride with risk evaluation via Quality by Design. Gözde Güncan, Gizem Yeğen, Burcu Mesut et al. Acta Pharm. Sci. 2017. Iss. 22 (2). P. 57-76.

ISSN 2312-0967. Pharmaceutical review. 2021. № 2 
28. Bhattacharya J. Quality risk management - understanding and control the risk in pharmaceutical manufacturing industry. IJPSI. 2015. No. 4. P. 29-41.

29. Sandipan Roy. Quality by design: A holistic concept of building quality in pharmaceuticals. Int. J. Pharm. Biomed. Res. 2012. No. 3. P. 100-108.

30. Quality by design (QbD): A complete review. N. P. Nadpara, R. V. Thumar, V. N. Kalola, P. B. Patel. Int. J. Pharm. Sci. Rev. Res. 2012. Iss. 17. P. 20-28.

31. Jain S. Quality by design (QbD): A comprehensive understanding of implementation and challenges in pharmaceuticals development. Int. J. Pharm. Sci. 2013. No. 6. P. 29-35.

32. A quality by design ( $Q b D)$ case study on enteric-coated pellets: Screening of critical variables and establishment of design space at laboratory scale. Shuling Kan, Jing Lu, Jianping Liu et al. AJPS. 2014. No. 9. P. 268278.

33. Developing micro-nanoparticulate drug delivery systems using "Design of experiments". Shuling Kan, Jing Lu, Jianping Liu et al. Int. J. Pharma Investig. 2011. No. 1 (2). P. 75-87.

34. Hesham M. Tawfeek, Jelan A. Abdel-Aleem, Mahmoud M. Ahmed. Development and optimization of itopride hydrochloride fast disintegrating tablets using factorial design and response surface methodology. Inter-

\section{References}

1. Hroshovyi TA, Demchuk MB, Beley NM, Naida YV, Pavliuk BV. [Experimental design in research at the creation of tablet medicines. Message 1. Design of the experiment in the study of the influence of qualitative factors at the stage of development at the stage of development of tablet drugs]. Farmatsevt chasop. 2020;2:10110. DOI: 10.11603/2312-0967.2020.2.11204 Ukrainian.

2. Hroshovyi TA, Demchuk MB, Beley NM, Pavliuk BV, Fizer LV. [Experimental design in research at the creation of tablet medicines. Message 2. Design of the experiment in the study of the influence of quantitative factors at the stage of optimizing the composition and technology of tableted drugs]. Farmatsevt chasop. 2020;3:70-9. DOI: 10.11603/2312-0967.2020.3.11428 Ukrainian

3. Hroshovyi TA, Demchuk MB, Pavliuk BV, Beley NM, Fizer LV, Makanchuk NV. [Experimental design in research at the creation of tablet medicines. Message 3. Using the method "Quality by Design" (QbD) in optimizing the composition and technology of tablet drugs]. Farmatsevt chasop. 2021;1:76-85. DOI: 10.11603/2312-0967.2021.1.11938. Ukrainian.

4. Pharmaceutical Quality by Design: A practical approach. Walkiria S. Schlindwein, Mark Gibson. John Wiley \& Sons Ltd. 2018.

5. Rayaprolu BM. Quality by design: A brief introduction. Journal of Pharmacovigilance. 2015;3(4): e142.

6. Guidance. Pharmaceutical development ( $\mathrm{ICH}$ Q8). [Настанова СТ-Н 42-3.0:2011. Лікарські засоби. Фармацевтична розробка (ICH Q8)] Kyiv; 2011. Ukrainian. national Journal of Pharmaceutical Sciences and Research. 2015. Vol. 6 (4). P. 1661-1672.

35. Hardik Patel, Shraddha Parmar, Bhavna Patel. A comprehensive review on quality by design (QbD) in pharmaceuticals. Int. J. Pharm. Sci. Rev. Res. 2013. Iss. 21 (1). P. 223-236.

36. Use of factorial design for evaluation of factors affecting the chemical stability of Sirolimus (Rapamycin) in solid dosage form. Aleksander Bajc, Janez Ker, Simona Bohanec. Acta Chim. Slov. 2012. Iss. 59. P. 156-162.

37. Quality by design: understanding the formulation variables and optimization of metformin hydrochloride $750 \mathrm{mg}$ sustained release tablet by Box-Behnken design. Young-Lae Lee, Min-Soo Kim, Myung-Yong Park et al. Journal of Pharmaceutical Investigation. 2012. Iss. 42. No. 4. P. 213-220.

38. Chandrakala V., Mary Saral A. Quality By Design approach in formulation of bioadhesive levodopa microspheres. Int. J. Pharm. Pharm. Sci. 2013. No. 5. P. 172-178.

39. Applying QbD approach to develop ODTs containing aceclofenac solid dispersion with ranitidine $\mathrm{HCl}$ using direct compression technique, then pharmaceutically evaluating and pharmacologically confirming the therapeutic actions. M. A. El-Nabarawi, M. F. El-Miligi, I. A. Khalil et al. IJPPS. 2013. No. 5 (4). P. 577 IA 593.

7. Ohage E, Iverson R, Krummen L, Taticek R, Vega M. QbD implementation and post approval lifecycle management (PALM). Biologicals. 2016;44:332-40. DOI: 10.1016/j.biologicals.2016.06.007

8. Guidance. Quality risk management ( $\mathrm{ICH}$ Q9). [Настанова СТ-Н 42-4.2:2011. Лікарські засоби. Управління ризиками для якості (ICH Q9)] Kyiv; 2011. Ukrainian.

9. Guidance. Pharmaceutical quality system (ICH Q10). [Настанова СТ-Н 42-4.3:2011. Лікарські засоби. Фармацевтична система якості (ICH Q10)] Kyiv; 2011. Ukrainian

10. Patwardhan DM, Amrutkar SS, Kotwal TS, Wagh MP. Application of quality by design to different aspects of pharmaceutical technologies. Int J Pharm Sci Res. 2017;8(9): 3649-62. DOI: 10.13040/IJP. SR.0975-8232.8(9).3649-62

11. Dipen Gaykar, Saurabh C. Khadse. A review on anaIytical quality by design. Int J Pharm Sci Rev Res. 2017;44(2): 96-102.

12. Shirsat AE, Chitlange SS. Application of quality by design approach to optimize process and formulation parameters of rizatriptan loaded chitosan nanoparticles. J Adv Pharm Technol Res. 2015;6(3): 88-96. DOI: $10.4103 / 2231-4040.157983$

13. De Beer TR, Wiggenhorn M, Hawe A, Kasper JC, Almeida A, Quinten T, Friess W, Winter G, Vervaet C, Remon JP. Optimization of a pharmaceutical freezedried product and its process using an experimental design approach and innovative process analyzers. Talanta. 2011;83(5): 1623-33. DOI: 10.1016/j.talan-

ISSN 2312-0967. Фармацевтичний часопис. 2021. № 2 
ta.2010.11.051

14. Mogal V. A review on quality by design. Pharm Biol Eval. 2016;3: 313-9.

15. Arijit Gandhi, Chandrani Roy. Quality by design (QbD) in pharmaceutical industry: Tools, perspectives and challenges. Pharma Tutor. 2016;4(11): 12-20.

16. FDA CDER. Draft guidance for industry and review staff. Target product profile-strategic development process tool, March 2007. Available from: http://www. ncai-cc.ccf.org/skills/documents/U.S.\%20FDA\%20 Target\%20Product\%20Profile\%20Guidance\%20Document\%20(2007).pdf

17. Yu LX, Lionberger R, Olson MC, Johnston G, Buehler G, Winkle $\mathrm{H}$. Quality by design for generic drugs. Pharm Tech. 2009;33: 122-7.

18. Patil AS, Pethe AM. Quality by design (QbD): A new concept for development of quality pharmaceuticals. IJPQA. 2013;4: 13-9.

19. Gupta Anuj, Neeraj Kumar Fuloria. Short review on quality by design: A new era of pharmaceutical drug development. Int J Drug Dev Res. 2012;4(3): 19-26.

20. Aksu B, Mesut B. Quality by design (QbD) for pharmaceutical area. J Fac Pharm Istanbul. 2015;45(2): 23351.

21. Mesut B, Aksu B, Özsoy Y. The place of drug product critical quality parameters in quality by design (QBD). Turk J Pharm Sci. 2015;12(1): 75-92.

22. Hales D, Vlase L, Porav SA, Bodoki A, Barbu-Tudoran $\mathrm{L}$, Achim $\mathrm{M}$, Tomula I. A quality by design (QbD) study on enoxaparin sodium loaded polymeric microspheres for colonspecific delivery. Eur J Pharm Sci. 2017;100: 249-61. DOI: 10.1016/j.ejps.2017.01.006

23. Kumar Deepak, Ancheria Rahul, Shrivastava Saumya, Soni Shankar Lal, Sharma Vandana. Review on pharmaceutical quality by design (QbD). Asian JPRD. 2019;7(2): 78-82. DOI: 10.22270/ajprd.v7i2.460

24. Lourenço FR, Francisco FL, Ferreira MRS, Pinto TJA, BouChacra NA. Design space approach for preservative system optimization of an anti-aging eye fluid emulsion. J Pharm Pharm Sci. 2015;18(2): 551-61. DOI: $10.18433 / J 3 J 600$

25. Santosh D. Borde, Sadhana R. Shahi, Kiran V. Kale, Ajit C. Jadhav, Durgesh R. Parakh. Formulation and evaluation of Paliperidone $\mathrm{HCl}$ mouth dissolving tablet by QbD approach. Pharm Biol Eval. 2016;6(3): 528-40.

26. Suciu S, Iurian S, Bogdan C, Iovanov R, Rus L, Moldovan M, Tomuta I. QbD approach in the development of oral lyophilisates with ibuprofen for paediatric use. Farmacia. 2018;66(3): 514-23. DOI: 10.31925/farmacia.2018.3.18

27. Gözde Güncan, Gizem Yeğen, Burcu Mesut, Buket Aksu, Yıldız Özsoy. Formulation design of the oral disintegrating tablets including alfuzosin hydrochloride with risk evaluation via quality by design. Acta Pharm
Sci. 2017;22(2): 57-76. DOI: 10.23893/1307-2080. APS. 05512

28. Bhattacharya J. Quality risk management - understanding and control the risk in pharmaceutical manufacturing industry. IJPSI. 2015;4: 29-41.

29. Sandipan Roy. Quality by design: A holistic concept of building quality in pharmaceuticals. Int J Pharm Biomed Res. 2012;3(2): 100-8.

30. Nadpara NP, Thumar RV, Kalola VN, Patel PB. Quality by design (QbD): A complete review. Int J Pharm Sci Rev Res. 2012;17: 20-8.

31. Jain S. Quality by design (QbD): A comprehensive understanding of implementation and challenges in pharmaceuticals development. Int J Pharm Pharm Sci. 2013;6: 29-35.

32. Shuling Kan, Jing Lu, Jianping Liu, Junlin Wang, Yi Zhao. A quality by design (QbD) case study on entericcoated pellets: Screening of critical variables and establishment of design space at laboratory scale. AJPS. 2014;9: 268-78.

33. Singh B, Bhatowa R, Tripathi C, et al. Developing Micro-Nanoparticulate Drug Delivery Systems Using "Design of Experiments". Int J Pharma Investig. 2011;1(2): 75-87. DOI: 10.4103/2230-973X.82395

34. Hesham M. Tawfeek, Jelan A. Abdel-Aleem, Mahmoud M. Ahmed. Development and optimization of Itopride Hydrochloride fast disintegrating tablets using factorial design and response surface methodology. International Journal of Pharmaceutical Sciences and Research. 2015;6(4): 1661-72.

35. Hardik Patel, Shraddha Parmar, Bhavna Patel. A comprehensive review on quality by design $(\mathrm{QbD})$ in pharmaceuticals. Int J Pharm Sci Rev Res. 2013;21(1): 223-36.

36. Petra Petelin Miha Homar, Aleksander Bajc, Janez Ker, Simona Bohanec. Use of factorial design for evaluation of factors affecting the chemical stability of Sirolimus (Rapamycin) in solid dosage form. Acta Chim Slov. 2012;59: 156-62

37. Young-Lae Lee, Min-Soo Kim, Myung-Yong Park, Kun Han. Quality by design: understanding the formulation variables and optimization of metformin hydrochloride $750 \mathrm{mg}$ sustained release tablet by Box-Behnken design. Journal of Pharmaceutical Investigation. 2012;42(4): 213-20.

38. Chandrakala V, Mary Saral A. Quality by design approach in formulation of bioadhesive levodopa microspheres. Int J Pharm Pharm Sci. 2013;5(4): 172-78.

39. El-Nabarawi MA, El-Miligi MF, Khalil IA, El- Nabarawy NA. Applying QbD approach to develop odts containing aceclofenac solid dispersion with ranitidine $\mathrm{HCl}$ using direct compression technique, then pharmaceutically evaluating and pharmacologically confirming the therapeutic actions. IJPPS, 2013;5(4): 577-93.

\section{Відомості про авторів}

Грошовий Т. А. - д. фрармац. наук, профресор, завідувач кафредри управління та економіки фрармації з технологією ліків, Тернопільський національний медичний університет імені І. Я. Горбачевського МОЗ України, Тернопіль, Україна. E-mail: grochovuy@ukr.net, ORCID 0000-0002-6427-2158.

ISSN 2312-0967. Pharmaceutical review. 2021. № 2 
Павлюк Б. В. - канд. фрармац. наук, асистент кафедри управління та економіки фрармації 3 технологією ліків, Тернопільський національний медичний університет імені І. Я. Горбачевського МОЗ України, Тернопіль, Україна. E-mail: bohdana.vons@gmail.com, ORCID 0000-0003-1276-0114.

Чубка М. Б. - канд. фрармац. наук, доцент кафедри фармації, Тернопільський національний медичний університет імені І. Я. Горбачевського МОЗ України, Тернопіль, Україна. E-mail: chubkacom@gmail.com, ORCID 0000-0002-56665496.

Демчук М. Б. - канд. фрармац. наук, доцент кафедри управління та економіки фрармації з технологією ліків, Тернопільський національний медичний університет імені І. Я. Горбачевського МОЗ України, Тернопіль, Україна. E-mail: pavljukm@tdmu.edu.ua, ORCID 0000-0002-9105-2302.

Найда Ю. В. - аспірант кафедри управління та економіки фрармації з технологією ліків, Тернопільський національний медичний університет імені І. Я. Горбачевського МОЗ України, старший інженер технологічної лабораторії центральної лабораторії фрармацевтичної розробки ПАТ «Фармак», Київ, Україна. E-mail: y.nayda@farmak.ua.

\section{Information about the authors}

Hroshovyi T. A. - DSc (Pharmacy), Professor, Head of the Department of Pharmacy Management, Economics and Technology, I. Horbachevsky Ternopil National Medical University, Ternopil, Ukraine. E-mail: grochovuy@ukr.net, ORCID 00000002-6427-2158.

Pavliuk B. V. - PhD (Pharmacy), Assistant Professor of the Department of Pharmacy Management, Economics and Technology, I. Horbachevsky Ternopil National Medical University, Ternopil, Ukraine. E-mail: bohdana.vons@gmail.com, ORCID 0000-0003-1276-0114.

Chubka M. B. - PhD (Pharmacy), Associate Professor, Department of Pharmacy, I. Horbachevsky Ternopil National Medical University, Ternopil, Ukraine. E-mail: chubkacom@gmail. com, ORCID 0000-0002-5666-5496

Demchuk M. B. - PhD (Pharmacy), Associate Professor of the Department of Pharmacy Management, Economics and Technology, I. Horbachevsky Ternopil National Medical University, Ternopil, Ukraine. E-mail: pavljukm@tdmu.edu.ua, ORCID 0000-0002-9105-2302.

Nayda Yu. V. - PhD student of the Pharmacy Management, Economics and Technology Department, I. Horbachevsky Ternopil National Medical University, Senior engineer of the Technological Laboratory of the Central Laboratory of Pharmaceutical Development at PJSC “Farmak”, Kyiv, Ukraine. E-mail: y.naida@farmak.ua 